\title{
O Inimigo em Pedaços: Um Ensaio de Discussão Bibliográfica acerca dos Tupi-Guarani
}

\author{
Márcio Marchioro ${ }^{1}$
}

\section{Introdução}

Esta pesquisa terá como intuito delinear as principais tendências historiográficas existentes na abordagem a respeito dos Tupi-Guarani. Nosso ponto de partida será a análise da bibliografia existente sobre os Tupinambás residentes na costa litorânea brasileira no século XVI. No que diz respeito a estrutura da pesquisa procuraremos dividi-la em três tópicos que versaram, de acordo com a bibliografia existente, sobre quatro temáticas essenciais: a demografia, a guerra, o canibalismo e o profetismo. Os assuntos da guerra e do canibalismo, que a nosso ver não podem ser secionados de modo algum, serão tratados em um capítulo conjunto.

No primeiro capítulo, nos ateremos as questões levantadas acerca do processo designado de invasão tupi do litoral, procurando discorrer um pouco sobre as características gerais dos primeiros habitantes da Mata Atlântica. Em seguida, temos objetivo de comentar as distintas hipóteses tecidas no que condiz a migração e o tempo de permanência dos Tupi-Guarani nas regiōes nas quais sua presença foi detectada pelos colonizadores no século XVI. Em uma breve passagem do ensaio, delimitaremos a área ocupada pelos Guarani, assim como dos Tupinambá, tentando fazer algumas considerações sobre a tese clastriana acerca das relações da demografia com o fortalecimento das chefias tupi-guaranis.

Já no segundo capítulo, faremos um pequeno apanhado das diferentes teses historicamente localizadas existentes sobre a relação da guerra com a religião tupi-guarani. Depois trataremos de abordar o assunto das categorias de idade tupinambá, tendo em mente a idéia de que elas são estruturadas a partir das atividades guerreiras. Outra questão importante a ser analisada é o tema do resguardo de nascimento por qual todo pai deve se submeter. Além disso, também temos por objetivo neste tópico comentar as relaçōes da guerra com a caça por meio da análise da mudança do discurso antropológico acerca deste tema. E, finalizando a seção, discorreremos sobre alguns aspectos da morte ritual do inimigo no terreiro e sua relaçẫo com o resguardo do matador.

Por último, em um terceiro capítulo, comentaremos como a mitologia tupi-guarani influi na decisão desses índios em buscarem a Terra Sem Mal, sem esquecer o fato de explicar a diferença entre o paraíso concebido pelos cristãos

\footnotetext{
${ }^{1}$ Graduação - História UFPR
} 
e o paraíso dos Tupi-Guarani. A diferenciação entre xamãs e caraíbas será também uma temática a ser analisada por nós em um trecho a seguir deste tópico. Em seguida, apresentaremos a teoria da alma presente entre alguns grupos guarani, buscando tecer algumas relações entre esses índios e os Kaingang. Finalmente, faremos um breve panorama das tendência de interpretação do fenômeno da busca da Terra Sem Mal tanto entre os TupiGuarani do século XVI como entre os Guarani do século XIX e XX.

\section{Distribuição Geográfica}

Existem poucos indícios arqueológicos capazes de possibilitar uma reconstrução fidedigna dos traços culturais característicos dos primeiros habitantes da região tropical, localizada no perímetro convencionalmente designado como terras baixas da América do Sul. Segundo o historiador ambiental Warren Dean (2002: 38), esses grupos humanos eram caçadorescoletores e, provavelmente, passaram por um período de escassez alimentar ocasionada graças à extinção de alguns animais de grande porte do cerrado. Com relação as justificativas elaboradas para explicar o surgimento da agricultura nessa região, Dean sustenta uma tese de teor prioritariamente demográfico. Ou seja, o autor dá preponderância a um aumento da população local, em detrimento da hipótese que aponta uma suposta mudança climática como principal fator contribuinte para desenvolvimento da horticultura indígena.

Além disso, a acidez do solo do cerrado tornou a área da Mata Atlântica - vegetação preponderante na costa litorânea brasileira do nordeste até o sul - preferida para o plantio de cultivares. O milho, o inhame, a abóbora, o abacaxi, o amendoim e, sobretudo, a mandioca, se constituíram, ao longo do tempo, como base da alimentação dos primeiros povos agricultores dessa paisagem florestal. O processo utilizado na feitura do plantio era o da lavoura itinerante, no qual ocupava-se determinada faixa de terra apenas durante duas ou três estações e, posteriormente, migrava-se criando outra delimitação para as hortas, deixando o solo anteriormente desgastado restabelecer-se. ${ }^{\dagger}$ Por outro lado, a falta de animais domesticáveis - como a lhama por exemplo - e o baixo rendimento da agricultura, fez com que as atividades de caça, pesca e coleta mantivessem sua importância fundamental na obtenção da base protéica indígena.

\footnotetext{
${ }^{1}$ Como nos diz John Hemming (1998: 104), “( ...) isso ocorre porque os solos lateríticos sob as florestas são fracos, os predadores e os parasitas atacam continuamente, a competição com outra vegetação é intensa e o sol inclemente e a chuva incessante, aliados a uma ausência de mudanças sazonais de temperatura, desestimulam o plantio repetido do mesmo solo".
} 

Explicando melhor, a região guarani possuía, segundo P. Clastres, cerca de $500 \mathrm{mil} \mathrm{km} \mathrm{km}^{2} \mathrm{em}$ seu total. Ao se descartar as áreas ocupadas por outras tribos, como os Kaingang, por exemplo, chega-se a um total aproximado de 350 mil km² ocupados apenas pelos Guarani. Através disso, a polêmica começa a se instalar no momento em que P. Clastres, pautado em dados de alguns cronistas quinhentistas, calcula que os Guarani pré-contato possuíam uma população de aproximadamente 1,5 milhões de índios. Contrariando essa tese, ao elaborar uma pesquisa regional sobre demografia guarani nos dois primeiros séculos da conquista, Bartomeu Melià (1988: 88) critica de forma veemente a metodologia adotada para a obtenção desses dados. De acordo com o seu ponto de vista, "los 'eléments de démografie amérindienne' de P. Clastres (...) no pasan de uma fantasia aritmética. Esse autor, a pesar de sus declaraciones de principio, no consideró necesario leer a los cronistas de un modo sistemático, apoyándose para sus cálculos en algunos datos de textos secundarios y parciales, que usa para fines decorativos (...)". A idéia central de P. Clastres (1986: 68-9) era propor que, por ocasião do aumento demográfico, os chefes tupi-guaranis poderiam reunir milhares de combatentes ao seu lado, fortalecendo, assim, sua influência perante à sociedade.

Conforme a visão clastriana, as entidades metafísicas designadas "sociedades primitivas" teriam antecipado o perigo representado pelo poder coercitivo nas mãos de um indivíduo, ou seja, conheceriam previamente o mal caracterizado pela imposição de um conjunto de pressupostos elaborados no exterior da sociedade. ${ }^{2}$ No caso especial das terras baixas sul-americanas, as sociedades indígenas seriam, então, compostas de grupos com pouca densidade demográfica vivendo em constante guerra, uns contra os outros. Mas, haveria uma exceção nesse modelo estrutural: P. Clastres (1986: 149) considera "os tupi-guaranis como um caso de sociedade onde começava a surgir o que teria podido se tornar o Estado".

Ao se debruçar sobre a teoria clastriana a respeito das sociedades primitivas, o antropólogo Marshall Sahlins pede cautela quando se pressupõe localizar nelas mecanismos que impedem a ascensão de uma instituição socialmente desconhecida como o Estado. Mesmo assim, ao confrontar uma ampla bibliografia, Sahlins reitera apenas a sugestão de P. Clastres referente ao poder ter uma origem exterior à sociedade. ${ }^{3}$ Além disso, sugere um

\footnotetext{
2 "Longe, portanto, de nos oferecer a imagem terna de uma incapacidade em resolver a questão do poder político, essas sociedades nos espantam pela sutileza com a qual elas a colocaram e regularam. Elas pressentiram muito cedo que a transcendência do poder encerra para o grupo um risco mortal, que o princípio de uma autoridade exterior e criadora de sua própria legalidade é uma contestação da própria cultura; foi a intuição dessa ameaça que determinou a profundidade de sua filosofia política" (P. Clastres 1986: 33).

${ }^{3}$ " $(\ldots)$ existe muito a ser criticado na noção de que as pessoas possam rejeitar a priori, por 'intuição' e 'premonição' um tipo de sociedade da qual jamais tiveram experiência. Mesmo assim,
} 
complemento a essa teoria, considerando a emersão do poder em uma sociedade como causa direta de uma "ruptura da ordem moral da população", isto é, a perpetração de "crimes contra o parentesco: fratricídio, parricídio, a união de mãe com filho, pai com filha, ou irmão com irmã” (Sahlins 1999: 112).

A forma de pensar os Tupi-Guarani defendida por P. Clastres, levanos a defini-los como completamente dispares no tempo. Em resumo, a sociedade configurada na época da conquista teria uma estruturação completamente distinta dos grupos remanescentes atuais. Fausto (1998: 381), por sua vez, discorda dessa imagem. No seu entender, apesar do cataclismo demográfico, os Tupi-guarani contemporâneos apresentam uma grande semelhança com os grupos do século XVI.

No que condiz à distribuição geográfica, referindo-se ao século XVI, como já pudemos evidenciar, os Guarani ocupavam áreas da bacia Paraná Paraguai, além de uma parte do litoral brasileiro da Lagoa dos Patos até Cananéia. A parte tupi abrangia desde Iguape até a costa do Ceará, ao longo da faixa litorânea, desconhecendo-se a dimensão da penetração pelo interior. A interrupção desse cotinuum tupi era feita "na foz do rio Paraíba pelos Goitacá, pelos Aimoré no sul da Bahia e norte do Espírito Santo, e pelos Tremembé na faixa entre Ceará e Maranhão" (ibid.: 382).

Então, a partir do momento do contato, os portugueses se depararam com essa enorme faixa litorânea tupi e, também, com um conjunto de microssociedades geralmente compostas de caçadores-coletores. Para designar genericamente esse amplo panorama culturalmente diverso, criou-se o binômio Tupi-Tapuia. Segundo John Manuel Monteiro (1995: 19-20), as duas categorias são dotadas de sentido, na medida em que expressam duas formas de estruturação social completamente dispares. De acordo com as classificações da antropologia contemporânea, sabe-se que os grupos taputias pertenciam a vários troncos culturais e lingüísticos, dentre os mais importantes estão os Jê, os Caribe e os Aruaque. Além disso, como se refere Fausto (1998: 383), haviam divisões internas entre os Tupi, distribuídas geograficamente da seguinte forma:

(...) os Tupiniquins de Cananéia até Bertioga - incluindo o planalto paulista; os Tupinambá (também chamados, nesta regiāo, Tamoio) do norte de São Paulo até Cabo

os tui da África Ocidental, refletindo sobre suas próprias circunstâncias políticas comparáveis, dizem que 'os homens chegam ao poder pela devoração da substância dos outros'. É de mesmo tom a saudação mais respeitosa que pode ser feita por um reles plebeu de Fiji a seu chefe: 'me coma'. Portanto, não é de surpreender que tal negação do poder, reivindicada por Clastres para a América do Sul, encontre eco até mesmo na divindade com a qual os polinésios - do mesmo modo que os indo-europeus da idade clássica - cercavam os seus reis. 'Os chefes havaianos eram considerados como deuses por causa da morte de um súdito', observa um sábio nativo. Porém, como diz um outro, 'alguns dos antigos reis tinham um medo saudável do povo"” (Sahlins 1999: 108). 
Frio, dominando inclusive o vale do Paraíba; Temomino, em áreas da baía de Guanabara. Entre o Espírito Santo e o sul da Bahia aparecem novamente os Tupiniquins; mais ao norte, os Tupinambá, que dominam o recôncavo baiano e se estendem daí até a foz do São Francisco - em cujo sertão vivem os Tupinaé. Daí até a Paraíba era território kaeté e os numerosos Potiguar espalhavam-se do extremo nordeste da costa até o Ceará. No início do século XVII, os cronistas encontrarão os Tupinambá no Maranhão, no Pará e na ilha de Tupinambarana, no médio Amazonas.

Os Tupinambá, objetos principais de nosso enfoque, tinham a guerra como principal instituição social. Suas aldeias compunham-se de unidades menores, configuradas em torno de um pátio central, denominadas malocas. Conforme Florestan Fernandes (1963: 64-70), um grupo local tinha em média 4 malocas, chegando a um máximo de 7 cabanas. Cada aldeia possuía de 500 até 3 mil indivíduos, sendo que "cada família, no caso do homem ter uma só esposa, ou cada esposa da família polígina, dispunha de uma área exclusiva da maloca, chamada lanço ou rancho". Dessa maneira, a aldeia constituía-se a unidade básica da vida social tupinambá, contudo, operações como a guerra e a antropofagia ritual, permitiam associações maiores entre grupos locais vizinhos, sem a constituição de nenhuma forma de domínio.

Dentre as características mais relevantes dos Tupinambá estava o conhecimento de técnicas agrícolas e, por isso, uma das principais funções do xamã consistia em trazer chuva para suas plantações. Sem suprimir as atividades de caça, pesca e coleta, "os tupinambás cultivavam diversos produtos, entre eles feijão, milho, várias espécies de tubérculos e abóbora, mas era a mandioca o seu principal alimento" (Schwartz 1988: 41). Segundo Egon Schaden (1974: 43), os povos de língua guarani, ao contrário, tem a sua lavoura - e por consequiência sua alimentação - pautada no cultivo do milho. O produto base para a preparação da chicha, sua bebida alcóolica mais tradicional, também é o milho e, além disso, pode-se considerar o calendário econômicoreligioso guarani pautado em torno desse cultivo.

Geralmente os Tupinambá se deslocavam de suas aldeias a cada três ou quatro anos, impulsionados, principalmente, pelo desgaste do solo. De acordo com Monteiro (1995: 21), "a diminuição das reservas de caça, a atração de um líder carismático, uma disputa interna entre facções ou a morte de um chefe", também eram motivos para a execução de migrações entre os Tupinambá. Outra característica básica das sociedades indígenas, assim como dos Tupinambá, é a existência de uma divisão sexual do trabalho: enquanto os homens caçam e pescam, as mulheres ficam incumbidas do plantio, da colheita e da preparação dos alimentos.

A chefia tupinambá, por sua vez, se desenvolveu em três níveis distintos: os líderes da maloca, do grupo local e, por último, líderes de caráter supra-local quando, em situação de guerra, laços recíprocos uniam várias aldeias contra um inimigo comum. Conforme a ampla literatura etnográfica nos 
mostra, os chefes indígenas não eram dotados de nenhum privilégio de cunho sócio-econômico (ibid.: 23). Nas palavras de P. Clastres (1982: 107), as sociedades primitivas seriam, então, caracterizadas pelas duas seguintes peculiaridades: "aqueles a quem se denomina líderes são desprovidos de todo poder e a chefia se institui no exterior do poder político".

A síntese da antropologia clastriana consiste na idéia de que sociedades inseridas na categoria de primitivas não conheceriam, de forma alguma, instituições como o mando e a obediência a uma pessoa, exceto em ocasiões muitos especiais como no caso de uma incursão guerreira dirigida contra o inimigo. Nas sociedades indígenas, desse modo, a capacidade de ser um chefe se desenvolveria junto com a habilidade da retórica, isto é, os líderes são os senhores das palavras, sendo que ninguém se opõe a esse monopólio da linguagem por parte dos chefes. No entanto, possuir o epíteto de chefe não é apenas ter o direito sobre as palavras. Em oposição, ser líder é um grande encargo social, pois esse sujeito é coagido a se pronunciar diariamente e, nos momentos de tensão, cabe ao chefe, também, tecer alianças mais amplas, recorrendo a afins em outras aldeias, ou mesmo, por meio da diplomacia, buscando estabelecer um período de paz com o inimigo.

Pautado nisso, segundo P. Clastres (1986: 107), "falar é para o chefe uma obrigação imperativa, a tribo quer ouvi-lo: um chefe silencioso não é mais um chefe". O grande paradoxo desse esquema consiste no fato claramente evidenciado da ausência de ouvintes no momento do discurso proferido constantemente pelo chefe. Nesse sentido, durante o tempo usado pelo líder para enfatizar, através de um longo palavreado, a importância de se seguir as tradições legadas pelos ancestrais míticos, as demais pessoas da aldeia fingem não ouvi-lo, continuando a desenvolverem suas atividades rotineiras normalmente.

$\mathrm{E}$, no intuito de defender a sua tese fundamental do líder indígena como um indivíduo incapaz de impor suas opiniōes para o conjunto do social, P. Clastres (1982: 206) se utiliza tanto de dados fornecido pelos cronistas quinhentistas como pelos trabalhos etnográficos feitos junto aos indígenas americanos, chegando a conclusão de que "(...) quando um chefe procura impor seu próprio desejo de guerra à comunidade, esta o abandona, pois ela quer exercer sua livre vontade coletiva e não submeter-se à lei de um desejo de poder. Ao chefe que quer 'fazer de chefe', na melhor das hipóteses dá-se-lhes as costas; na pior, ele é morto".

Entretanto, como já nos referimos anteriormente, P. Clastres, a partir de cálculos demográficos, acaba formulando a sugestão, bastante discutível por sinal, de que os chefes tupinambás nos séculos XV e XVI não eram completamente destituídos de poder e, por isso, essa sociedade estava prestes a se configurar numa estrutura estatal. Fausto, por sua vez, discorda em boa parte 
dessa idéia, pois não havia entre os Tupinambá uma aldeia central onde residia um chefe supra-local dotado de um poder de comando sobre as demais. Baseado nessa observação dos cronistas do século XVI, Fausto (1998: 390) formula a seguinte hipótese:

A estrutura do poder depende do evento, da circunstância, dos caprichos do acontecimento. Esse é o caráter performativo da estrutura tupi (...): em vez de exorcizar o evento, faz dele uma variável estrutural, preservando sempre um resíduo de incerteza - não redutível à distinção norma e prática - que aponta para uma noçāo não elementar de 'regra'. Esse intervalo, esse 'resíduo de incerteza, é justamente o espaço do político na sociedade tupinambá.

A distinção notada por P. Clastres entre os chefe de paz - possuidor do monopólio das palavras - e os chefes da guerra consiste num primeiro indício muito importante do caráter inconstante da estrutura social tupi-guarani. Porém, segundo Fausto (2001: 320), P. Clastres parece exagerar quando pretende estender seu modelo, pois os dados etnográficos atuais comprovariam o caráter coercitivo de algumas lideranças sul-americanas. Os Parakanã da Amazônia índios estudados por Fausto -, em contraposição, concordam com o modelo construído por $\mathrm{P}$. Clastres, pois seus chefes são indivíduos que alcançam esse status por meios distintos da guerra, explicando mais detalhadamente, o líder entre esses índios não é erigido pela análise do seu currículo como matador, contudo, nada o impede de sê-lo.

\section{Guerra e Sacrifício}

Incumbidos da missão de converter os índios à fé católica, os jesuítas chegaram às terras brasileiras com uma bagagem repleta de confiança na possibilidade de transformar as populações nativas em crentes fiéis dos dogmas da Santa Igreja. Os grupos habitantes da costa litorânea, denominados genericamente de Tupinambá (conforme acima), não deram nenhuma demonstração de desprezo aos prenúncios ditados pelos padres recémchegados. Muito pelo contrário, quem tampou os ouvidos para não absorver nenhum elemento da cosmologia desses povos foram os europeus.

Então, os europeus ao chegarem no continente americano trataram seus habitantes como animais destinados a fazerem os trabalhos mais penosos em suas lavouras comerciais ou no transporte e retirada das riquezas naturais. Os colonos não interessados imediatamente na obtenção do lucro a partir da exploração da mão-de-obra nativa, observavam os índios como futuros e disciplinados cristãos. Os Tupinambá, por sua vez, transcendiam esse paradigma de pensamento na medida buscaram na alteridade dos europeus alguns requisitos provocadores de modificações em sua organização social, ao mesmo tempo, atributos necessários para perpetuá-la. 
Mas como poderiam esses indígenas aceitarem uma nova crença religiosa sem perseverar totalmente nela? Uma das possíveis respostas é proposição de que o pensamento nativo não é constituído, ou mesmo desconhece a noção de dogma. Nesse sentido, como propõe Eduardo Viveiros de Castro (2002: 217), “a validação da cosmologia nativa pelo recurso à palavra dos pajés e profetas não significa, portanto, uma 'crença' nesta palavra, no sentido político-teológico do termo, porque faltava exatamente o componente de sujeição, de abdicação do juízo e da vontade". Desse modo, a cultura tupinambá não era propícia a criação de discursos tidos como verdade incontestáveis. Segundo Viveiros de Castro (2002: 215), assim como os Araweté da Amazônia atual, os Tupinambá possuíam em sua língua artifícios pelos quais se poderia distingir nitidamente informações obtidas através do diálogo com outras pessoas das provenientes da experiência própria. Não há como questionar, no entanto, as grandes doses de prestígio perante os demais obtidas pelos xamãs e profetas tupinambás.

Porém, a ausência de dogma na concepção religiosa dos Tupi-Guarani, proposta por Viveiros de Castro não parece, de modo algum, ser uma unanimidade entre os especialistas. Curt Nimuendaju (1987: 76), por exemplo, considera o respeito aos preceitos ditados pelos pajés-principais o único motivo para a existência de uma resistência as tentativas fracassadas de aldeamento dos Guarani. No seu entender, "os índios opunham resistência passiva à nova administração; os ressentimentos mútuos cresciam, e um belo dia, por um motivo insignificante, todo o grupo se dispersava (...)". Outra visão discordante parece ser a de Hélène Clastres (1975: 44), pois, no seu entender, os relatos quinhentistas nos mostram a hostilidade dos índios para com os viajantes que tentavam convence-los da falsidade dos seus profetas. Analisando uma revolta dos Chiriguano no século XVIII, Daniel J. Santamaria (1996: 186) relata a recusa desses índios em a adotar as práticas cristãs, usando como justificativa o fato do deus Tumpa - entidade sobrenatural suprema - ter criado os espanhóis para o cristianismo e os Chiriguano para permanecerem Chiriguano.

Toda essa explanação inicial nos leva a tese, defendida por Florestan (1970: 17), do complexo guerreiro construído pelos Tupinambá no século XVI como uma instituição subordinada inteiramente ao "sistema mágico-religioso tribal". No entanto, pautado na análise de Viveiros de Castro (2002: 210), podemos chegar a conclusão exatamente oposta. Assim, não era a guerra perpetrada com o intuito de apaziguar o mundo sobrenatural, mas sim a religião que era carregada de pressupostos os quais incentivavam sobremaneira a feitura de expedições guerreiras contra o inimigo. Enquanto alguns países europeus do século XVI viviam as chamadas "guerra de religião", os Tupinambá da costa possuíam uma religião estruturada no sentido de valorizar a cultura bélica. 
Os relatos referentes aos "povos primitivos", isto é, às sociedade desprovidas de uma instituição social complexa como o Estado, são quase unanimes em afirmar o caráter belicoso desse tipo de formação social. Os Tupinambá não se distinguem dessa análise mais geral e, segundo os dados apurados pelos cronistas, a justificativa prática para motivar o preparo de expedições de ataque aos contrários era a vingança. Momentos como a reunião dos chefes e as cauinagens eram os mais propícios para o estabelecimento do consenso necessário para o início das preparações de guerra.

Pautado nisso, P. Clastres (1982: 186-7) coloca a guerra numa posição central dentro da análise de sociedades classificadas por ele como primitivas. Segundo essa abordagem, a guerra é tão natural nesse contexto porque a fragmentação social e a perpetuação do grupo local com sendo a unidade básica ameríndia dependem, sobremaneira, dela. Mais especificamente, a comunidade primitiva, interessada em preservar seu ideal autárquico, buscaria fazer guerra aos contrários com o objetivo de preservar o seu domínio perante um território culturalmente integrado a vida social.

Entre os Tupinambá, a guerra igualmente era percebida como sendo um momento no qual era necessário e benéfico a construção de alianças com outros grupos locais. O objetivo dessa precaução era clara: precisava-se proteger a retaguarda, pois se isso não fosse feito o inimigo o faria e, com isso, ao invés de se ter um aliado contraía-se um adversário potencial em suas proximidades. No entender de P. Clastres (1982: 201), a guerra é, então, uma instituição inscrita na essência dessas sociedades. No intuito de preservar sua imanência igualitária e autárquica, a guerra buscava "garantir a permanência da dispersão, da fragmentação, da atomização dos grupos”.

No contato com os padres jesuítas os Tupinambá, como diria Viveiros de Castro (2002: 225), eram tão inconstantes, não mostrando nem rejeição e nem engajamento total no que diz respeito aos desígnios da fé católica. Em contraposição, a guerra e a vingança permaneceram uma constante na sustentação da "máquina social dos povos da costa. (...) Eis o avesso da inconstância indígena". Diferentemente dos europeus, os Tupinambá não perpetravam seus embates em torno de seus ídolos religiosos. Sob a perspectiva dos jesuítas, as incursões guerreiras pautadas na vingança, consistiam a origem dos costumes reprováveis praticados por esses índios. O conjunto de rituais ligados com o caráter belicoso da sociedade tupinambá eram o canibalismo, as cauinagens e a poligamia, esta generalizada apenas entre os lutadores mais hábeis.

O antropólogo Carlos Fausto (2001: 270) considera que os "tupis da costa atlântica no século XVI (...) pensavam suas guerras como vendetas públicas, embora os europeus as vissem como guerras". Os combates tupinambás envolviam, geralmente, cerca de dois a três mil guerreiros num 
embate típico de sociedades igualitárias, na qual as ações armadas não possuíam qualquer tática e cada um utilizava suas habilidades pessoais numa luta extremamente individual. Pode-se crer, também, que ao voltar sua agressividade para o exterior, os Tupinambá evitavam rupturas maiores dentro do seu próprio grupo local.

Quadro 2.1: As categorias de idade dos homens tupinambás (Fernandes 1970)

\begin{tabular}{|c|c|c|c|}
\hline Categoria & Idade & Tutela & $\begin{array}{l}\text { Funções guerreiras ou } \\
\text { sociais possíveis }\end{array}$ \\
\hline $\begin{array}{c}\text { Mitã e } \\
\text { Kunumï-mirï }\end{array}$ & Até 8 anos & Mãe & 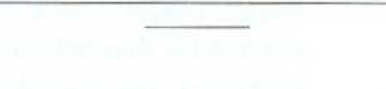 \\
\hline Kunumii & $\begin{array}{l}\text { Até } 14 \text { ou } 15 \\
\text { anos }\end{array}$ & Pai & $\longrightarrow$ \\
\hline Kunumï-guasú & Até 25 anos & Pai & $\begin{array}{c}\text { Provimento dos guerreiros } \\
\text { Impulsionar as canoas }\end{array}$ \\
\hline Avá & $\begin{array}{l}\text { Mais de } 25 \\
\text { anos }\end{array}$ & & $\begin{array}{c}\text { Guerreiro } \\
\text { Direito ao casamento }\end{array}$ \\
\hline Tujuáe & $\begin{array}{l}\text { Mais de } 40 \\
\text { anos }\end{array}$ & & $\begin{array}{c}\text { Chefe de maloca } \\
\text { Chefe de grupo local } \\
\text { Chefe de bando guerreiro } \\
\text { Pajé } \\
\text { Direito à Poliginia }\end{array}$ \\
\hline
\end{tabular}

A atividade guerreira em si era um empreendimento monopolizado pelos homens. Sendo assim, cabia a parte masculina adulta da sociedade tupinambá capturar o inimigo e sacrificá-lo para a realização do festim canibal. As mulheres se encarregavam do preparo do cauim, além de terem uma participação essencial nas cerimônias rituais de recepção do cativo. Entre os homens apenas três categorias de idade (conforme acima) poderiam participar de empresas bélicas. Os primeiros, por ordem crescente, eram os kunumï-guasú possuidores da incumbência de abastecer os guerreiros e impulsionar as canoas. A segunda abrangia os avá (homem) detentores de todas as capacidades de um 
guerreiro normal. Já os terceiros eram os tujuáe, os quais poderiam exercer funções de chefia durante os embates. Aos mais novos (categorias mitã, kunumi-miri e kunumí) não cabia nenhuma função guerreira, apenas participavam dos rituais antropofágicos.

Nesse sentido, tanto Viveiros de Castro como Florestan concordam com a conotação de rito de passagem atribuída ao primeiro sacrifico de um prisioneiro executado por um jovem tupinambá. Após esse ato, o indivíduo transcendia da categoria kunumï-guasú para a de avá, mudava de nome e passava a estar apto para se casar e ter filhos. Segundo os relatos, nenhuma mãe permitia que sua filha casasse com um kunumï-guasú, pois uma pessoa localizada nesta categoria de idade, não tendo executado nenhum inimigo, deixava de possuir os atributos necessários para desempenhar o papel de "pai" durante os ritos ocorridos em decorrência do nascimento de um possível filho seu.

O nascimento de um filho, assim como execução de um inimigo em praça pública, é na maioria das sociedades indígenas um momento de intenso resguardo principalmente para o pai social da criança. O respeito pela patrilinearidade se dá, desse modo, através de interditos alimentares e cuidados na realização de tarefas pertencentes ao cotidiano. No entender de Fausto (2002: 19), o parto em si "é a exteriorização de um processo interno de transformação, que costuma remontar à captura de um princípio vital externo". Por esse motivo, o período correspondente ao pós-natal é muito importante porque consiste num momento de determinação da "espécie" a qual pertencerá o recém-nascido. O pai, sobretudo, e os demais parentes do bebê devem medir todos os esforços necessários para fazer da criança uma pessoa humana aparentada.

Os Jurunas, índios do Xingu atual, possuem um exemplo singular de como as interdições são necessárias no sentido de que se forem feitas corretamente não haverá nenhum desvio no processo de transformação da criança. Segundo esse grupo, o bebê adquiri uma forma humana graças a intervenção alimentar feita durante o período de gestação. A mãe da futura criança é proibida terminantemente de comer qualquer tipo de carne, pois temese transmitir ao embrião características canibais típicas do tucunaré (Lima 1996: 27).

A observação do resguardo também é notada por Schaden (1974: 79) entre os Guarani que dizem "simplesmente que o fulano está akû". O termo akú seria utilizado para designar o período de reclusão e cuidados por qual estaria passando um pai após o nascimento de um novo rebento, a menina logo após a primeira menstruação e o menino depois de submetido à perfuração do lábio. Outra prescrição importante entre esses índios, seria a necessidade do homem permanecer em casa, não saindo para caçar, na iminência da esposa dar à luz. 
Infringindo essa regra, o homem guarani estaria em perigo graças ao odjépotá do pai. Entre os Ñandéva, no que diz respeito aos malefícios do odjépotá, existe um mito

de um homem que, desrespeitando as observâncias, vai para o mato, onde encontra um tadjatsú (queixada) em forma de mulher bonita, ao qual acompanha e que o leva para o meio dos queixadas. Ele fica vivendo no meio dos queixadas, tomando-os todos por gente (ibid.: 84 )

A instituição da poligamia entre os Tupinambá, como já nos referimos, também de acordo com os cronistas, se estendia apenas aos chefes ou aos habilidosos na arte da guerra. Esses homens, geralmente mais velhos e pertencentes à categoria tujuáe, graças ao fato de terem matado muitos inimigos, poderiam adquirir outras esposas. Nessa categoria de idade, "os indivíduos podiam ser chefes de malocas, de grupos locais, líderes guerreiros e pajés" (Fernandes 1970: 156). Por outro lado, haviam indivíduos não possuidores de atributos guerreiros, os quais eram tratados de forma depreciativa pelos companheiros de tribo, ganhando a designação de cuave eim.

Além disso, matar muitos inimigos era uma condição necessária para, depois de morto, o guerreiro ter acesso a sociedade dos antepassados (Guajupiá). Já as almas dos que se demostraram covardes durante a vida, permaneceriam vagando pela terra acompanhado pelos demônios (Anhang). Caso capturado por uma tribo inimiga, o guerreiro tupinambá deveria suportar com bravura todas as provações do cativeiro e do sacrifício.

No entender de Viveiros de Castro (2002: 231), "a devoração pelos inimigos estava associada a um tema característico das cosmologias tupiguaranis, o horror ao enterramento e a putrefação do cadáver". De acordo com P. Clastres (1982: 41), esse repúdio à carne em decomposição é comum nas cosmologias indígenas das terras baixas sul-americanas. No nordeste amazônico, por exemplo, existe entre os Yanomami um ritual peculiar de endocanibalismo executado após a morte de um membro do grupo local. Primeiramente, o corpo é incinerado em uma fogueira até quando toda a carne for queimada. Em seguida, os Yanomami retiram os ossos do local de incineração e, através da pilagem, os transformam em pó mantendo-os numa cabaça. "À medida que as necessidades cerimonias se apresenta, são consumidos, misturados com banana amassada”.

No entender de P. Clastres (1982: 175), não se pode cair no equívoco de justificar a guerra, onipresente em sociedades não-estatais, através de um discurso de concepção naturalista. Considerando esse ponto de vista, os caçadores humanos teriam desenvolvido recursos bélicos mais precisos e, com isso, tornaram-se guerreiros. Para o autor, essa perspectiva evolucionista busca permanências jamais existes, pois os fatos humanos não podem ser 
biologizados. Dessa forma, a partir de quando o homem deixou a condição de animalidade, na sua concepção ocorrida quando os casamentos exogâmicos começaram a ocorrer, não se pode mais naturalizar as explicaçôes a respeito as ações humanas.

A diferença da guerra e da caça, para P. Clastres (1982: 176), seria que a primeira tem um componente a mais e distinto da segunda: a agressividade. A permanência dos mesmos artigos técnicos tanto na caça como na guerra não resultariam, desse modo, na identificação imediata das duas práticas, "Pois, se a guerra é a 'réplica' da caça, então a antropofagia generalizada é seu horizonte". Ou seja, a guerra não contraiu nenhuma dívida para com a caça, os embates não ocorrem graças a natureza da espécie humana, ao contrário, a guerra pertence ao domínio da cultura, se inscreve no âmbito das relações sociais humanas.

Ao se referir à Amazônia indígena, Viveiros de Castro parece concordar com a visão acima nos termos em que esse discurso naturalista estaria propondo uma espécie de "animalização" do inimigo como concepção geral das sociedades não-estatais. Por outro lado, segundo ele, os índios habitantes da floresta Amazônica, em linha gerais, não concebem as relações do homem com a natureza como sendo naturais. Pautado no conceito de "perspectivismo", formulado por Viveiros de Castro (2002: 286), podemos dizer que os indígenas percebem essas relações como pertencentes ao campo sociedade, isto é, as relações entre humanos e animais são relações sociais. Conscientes disso, ao interpretar o resguardo a que é submetido o matador do inimigo nas sociedades indígenas, podemos perceber uma certa continuidade com quando o caçador é impedido de se alimentar da própria caça, por sinal, uma prática bastante difundida entre os ameríndios.

Entre os Tupinambás, o resguardo do matador também era uma prática obrigatória. Após o massacre da vítima, o executor, responsável por desferir o golpe fatal com o tacape de modo que o crânio da vítima fosse esfacelado, não poderia participar do restante do ritual, sendo terminantemente impedido de se alimentar das partes do cativo. Conforme Florestan (1970: 290), "o sacrifício da onça se realizava sob forma ritual, do mesmo modo que o de seres humanos (...)". Isso se explica a partir da cosmologia tupinambá que, de acordo com o conceito de perspectivismo, concebia o jaguar como o mais humano dos animais. Melhor dizendo, num passado mitológico todos os animais eram humanos, em seguida houve a diferenciação que, porém, não abstraiu a capacidade dos próprios animais de se enxergarem como humanos. Por isso, criou-se uma gradação dos seres e, entre os Tupi da costa no século XVI, o jaguar ocupava o maior grau dessa escala hierárquica, em resumo, esse mamífero era tratado como quase um humano.

O antropólogo Carlos Fausto, ao estudar os índios Parakanã, remanescentes dos grupos tupis, reafirma a hipótese de Viveiros de rastrn. 
Conforme Fausto (2001: 262), "quando se pergunta sobre o sexo de uma criança ou de um bicho, só há um par de termos possíveis como resposta: kojoa ou akoma'e". Então, ao se fazer uma aproximação com o português, vemos que os Parakanã não criaram, para designar seus filhos, termos correspondentes a "menina" e "menino", respectivamente, possuidores de uma conotação claramente humana. Continuando a analogia com o português, podemos observar nesses índios a classificação dos recém-nascidos com substantivos correspondentes a macho e fêmea, usados corriqueiramente para diferenciar o sexo dos animais. Os Parakanã se nomeiam pela designação awaeté (humanos verdadeiros), sendo que o vocábulo awa é usado para opor tanto homemlmulher quanto humanolnão-humano. Por fim, conclui-se que os Parakanã possuem "três categorias para duas oposiçōes: uma aplicada à distinção sexual de animais e humanos (akoma'e kojoa), e outra referindo-se apenas ao gênero destes últimos (awa kojoa)". Os animais não são designados $a w a$, ou seja, não são humanos, "embora no universo dos sonhos possam 'fazer-se humanos', -je-mo-awa", enquanto "os inimigos humanos são também - e disto não se duvida - awa".

As culturas de âmbito florestal tropical, a partir da noção de perspectivismo, não acreditam na morte definitiva dos animais. Assim, alvejados pelos caçadores, os animais só morrem aos olhos dos humanos. A quase total ausência de preocupação com os restos corporais dos animais ocorre devido a crença na regeneração, isto é, ao serem mortos e destituídos da carcaça os animais despiriam uma espécie de roupa transformando-se em uma nova entidade. As práticas observadas antes da refeição se inserem, então, num conjunto de crenças pautadas no tratamento ético da caça para se evitar a inversão de perspectivas. Explicando melhor, os tabus e os rituais xamânicos executados sobre o animal morto minimizavam a possibilidade do caçador se tornar uma presa.

Antes de partir para a guerra, além da confecção dos aparatos bélicos, havia espécies de ritos nos quais um pajé interpretava um relato de sonho. Esses ritos tinham um caráter premonitório e dariam aos Tupinambá as condições de saberem se a incursão guerreira seria ou não bem sucedida. Segundo Florestan (1970: 77), "quando os sonhos evidenciavam a segunda alternativa, desistiam da expedição guerreira projetada”. Do contrário, após a execução dos rituais necessários, o bando guerreiro partia em busca do inimigo.

Os grupos locais ou aldeias eram as unidades sociais básicas da vida dos Tupi quinhentistas. Dentro da aldeia existiam várias malocas divididas geralmente entre pessoas ligadas por laços de parentescos. Por vezes uma aldeia se colocava em posição defensiva e em outras ofensiva, sendo que grupos locais sem parentes afins tinham uma relação de rivalidade quase intensa. Entretanto, entre os Tupinambá tanto as expedições guerreiras como a 
participação nos rituais antropofágicos permitiam a criação de aliança entre grupos locais distintos.

No combate bélico em si, para afugentar o inimigo de suas malocas, os Tupinambá poderiam usar flechas incendiárias. Segundo P. Clastres (1982: 17), os Yanomami nos oferecem o maior exemplo de como eram as guerras indígenas antes e nos momentos iniciais da conquista. $\mathrm{O}$ autor nos deixa a impressão da guerra yanomami como sendo iniciada por um ataque surpresa de modo que "flechas são atiradas por cima do teto". Ao cair, as flechas normalmente fazem alguns feridos e dificilmente alguns mortos. Então, o grupo apanhado de surpresa pelo ataque se organiza e parte para o contra-ataque. Dessa maneira, os costumes guerreiros entre os Yanomami são tão arraigados quanto eram nos Tupi do século XVI, sendo que "os meninos praticam jogos freqüentemente brutais, coisa rara entre os índios, e os pais evitam consolá-los quando, após levar uma paulada na cabeça, ocorrem aos berros: 'Mãe! Ele bateu em mim!' 'Bata nele com mais Força!' O resultado - proposital - desta pedagogia é que ela forma guerreiros" (ibid.: 24).

Como já vimos, os combates tupinambás tinham por objetivo, entretanto, capturar um inimigo vivo. Essa façanha era feita na maioria das vezes de forma individualizada, ou seja, cabia apenas a uma pessoa a honra de desarmar e aprisionar o inimigo. Depois disso, o cativo era levado para a aldeia e, por um breve momento, as relaçōes entre o futuro matador e a vítima eram cortadas. A recepção do prisioneiro, em si, com certa regularidade, se fazia debaixo de palavras e gestos agressivos: as crianças e as mulheres da aldeia eram os primeiros a agredir fisicamente o recém-chegado.

Os cronistas do século XVI não conseguiam conceber a lógica da guerra tupinambá, pois esses índios andavam muitos quilômetros para combater os seus contrários e, chegando ao local, confrontavam com o inimigo no intuito de fazer alguns poucos prisioneiros vivos. Durante a permanência do cativo na aldeia, até a sua execução para o posterior ritual antropofágico, buscava-se qualificar o indivíduo, ou seja, os Tupinambá não se preocupavam com a quantidade de inimigos, mas sim em distinguir o inimigo com o objetivo de socializá-lo e não animalizá-lo.

De acordo com Fausto (2001: 298), “a máquina antropofágica tupinambá permitia, precisamente, construir essa distância ótima e não tomá-la como dada. O cativo - fosse ele um francês, um tapuia, outro tupi ou um português - acabava aprendendo os modos, as falas e as disposições necessárias". Viveiros de Castro (2002: 231), no entanto, parece discordar dessa afirmação quando diz que "a cumplicidade entre cativo e captores (...) fazia com que o inimigo ideal de um tupinambá fosse outro tupinambá". Para confirmar sua tese, utiliza como argumento de comprovação, o ritual de depilação e ornamentação do cativo executado no prisioneiro pelas mulheres. 
Na sua visão, nesse momento, o inimigo passava a ter uma aparência física semelhante aos habitantes do grupo local pelo qual havia sido aprisionado.

Cabe ressaltar que entre os Tupinambá o prisioneiro poderia viver alguns anos livremente na aldeia de seus captores, porém, o inevitável já estava previamente estabelecido, o cativo seria, depois de um certo tempo, morto e devorado. Por isso, com um destino marcado, o indivíduo capturado estava excluído de sua comunidade original. Caso houvesse uma fuga o cativo estaria desonrando seus parentes, pois o fato deixava implícita a descrença do prisioneiro nas capacidades bélicas de seus amigos em vingá-lo futuramente.

$\mathrm{O}$ curioso é notar, no que condiz as formulações indígenas acerca do inimigo ideal, que os Araweté da Amazônia, índios possuidores em sua cosmologia de divindades antropófagas (os Maỉ), consideram o ser ideal aquele indivíduo capaz de misturar "traços araweté e inimigos" (ibid.: 269). Graças a isto, os deuses araweté são marcados por uma profunda ambivalência, pois eles transmitem a esses índios uma idéia do homem mais digno como sendo aquele que já matou pelo menos um inimigo.

Para integrar o inimigo definitivamente à aldeia, os Tupinambá lhe davam um lugar para morar, geralmente a maloca do seu futuro algoz, além de uma esposa para os serviços domésticos e sexuais. Sua atuação na sociedade era pouco restringida de modo que "dispunham da mesma liberdade que os demais para escolher as atividades rotineiras com seu sexo e idade (...)" (Fernandes 1970: 256). No que concerne ao tempo de convivência do cativo entre os inimigos até ser executado, podemos dizer que variava de acordo com o sexo e a idade. Caso ele fosse ferido gravemente durante a batalha, não havendo como remediar sua morte, o sacrifício ocorria num dos acampamentos e, posteriormente, já no âmbito da aldeia, esfacelavam-lhe o crânio e ingeriam sua carne.

De acordo com o que escreveu Florestan (1970: 275), existiam dois tipos de sacrifício humano entre os tupis quinhentistas: o primeiro se dava para restabelecer o mundo espiritual abalado graças à uma morte recente, seja ela perpetrada por um inimigo, por velhice ou por doença; o segundo alimentaria os ancestrais míticos. Viveiros de Castro (2002: 240), em sua análise a respeito dos Tupinambá, demostra discordar dessa concepção "fria" desses índios. Segundo o autor, o canibalismo tupi-guarani não fala do passado, não pressupõe um restabelecimento da ordem prescrita. Em síntese, ele "não era uma daquelas tantas máquinas de abolir o tempo, mas uma máquina de produzilo, e de viajar nele (...)".

Para Viveiros de Castro (2002: 241), a vingança tupinambá, explicitada no ritual antropofágico, renovava, a cada instante, a relaçāo com o inimigo. Nele estavam em jogo a necessidade da preservação da alteridade como pressuposto máximo na conservação da autonomia da comunidade. Nesse 
sentido, a vingança não era um modo de restabelecer a relação com o sobrenatural, mas sim um modo de perpetuação da sociedade, na medida em que ela "existia por e para os inimigos".

Após o término do período marcado previamente nas cerimônias de recepção, estava em tempo do cativo ser sacrificado. Dessa maneira, era preciso desfazer os laços os quais prendiam o inimigo ao grupo local. Feito isto, realizavam-se cerimônias no sentido de restabelecer as ligaçōes do cativo com o grupo rival de origem. Seu corpo era decorado conforme os traços e adereços associados ao inimigo e, em seguida, o prisioneiro era solto, devendo lutar pela sua liberdade até ser preso novamente. Posteriormente, havia um rito de demonstração da agressividade do oponente, "nessa ocasião, eles podiam atirar pomos de jenipapo e outros projéteis, como pedaços de raízes e cacos (...) nos seus algozes, sendo-lhes permitido, inclusive, utilizar o arco com flechas rombudas" (Fernandes 1970: 283).

Depois de dois ou três dias de cantos, danças e cauinagens, finalmente o prisioneiro era levado ao local da execução. Ocorria, então, um diálogo com o matador em que se perguntava ao cativo se ele era um membro oriundo da tribo que havia matado e devorado muitos de seus parentes e amigos. A resposta sempre soava no sentido da promessa da continuidade da relação entre os inimigos. Geralmente o inimigo gabava-se de ter matado e devorado muitos dos parentes e amigos dos presentes, postulando igualmente uma vingança futura perpetrada pelos membros do seu grupo.

Finalmente, após observado toda essa gama de rituais, o massacre se dava no terreiro da aldeia. O matador, munido com um tacape, esperava o momento certo, desferindo um golpe fatal na região da nuca de modo que o crânio da vítima fosse esfacelado. Segundo Fausto (2001: 458), cada ato da complexa cerimônia (rapto, reinimização, recaptura, execução) permitia a quem realizasse o feito adquirisse um novo nome. Visão esta aparentemente um pouco exagerada, pois, para Viveiros de Castro, apenas o esfacelamento do crânio de um inimigo, esteja ele vivo ou morto, concedia ao executor o direito de tomar um novo nome. ${ }^{4}$

$\mathrm{O}$ ato canibalístico era de caráter público, ou seja, todos os participantes deveriam devorar as partes do morto devidamente moqueadas. Segundo Florestan (1970: 296), as crianças, os jovem e as mulheres compartilhavam da cerimônia através da ingestão de um mingau feito com o intestino e outros órgãos internos do sacrificado. Os homens guerreiros (avá e tujuáe), exceto o matador, devoravam o restante do corpo da vítima. Ao analisar o canibalismo tupi, Viveiros de Castro (1985: 55-90) propõe a seguinte hipótese: a antropofagia do inimigo significa (ou melhor dizendo, ela faz) uma

4..(...) requisito crucial para a obtenção de um novo nome, era o esfacelamento ritual do crânio do contrário (...)". (Castro 2002: 258). 
relação com o "Outro" não reprodutora de uma imagem da sociedade previamente constituída. Nesse sentido, ela não representa "uma necessidade simbólica que poderia ser 'satisfeita' por meios mais sutis”. Em oposição, a antropofagia é o ponto máximo no qual um indivíduo não encontra mais um par contrário, pois a partir disso essa pessoa (ou sociedade) passa a se projetar como o "Outro".

Nas palavras de Fausto (2002: 27), “a antropofagia guerreira tupinambá expressava-se na linguagem do desejo alimentar e da vingança. A carne humana era consumida porque doce e saborosa, e porque todos queriam ou deviam vingar-se do inimigo". O ato antropofágico era definidor de dois tipos distintos de relação: a primeira era de aliança e a segunda de predação. A relação de aliança era produzida - como ocorre na maioria dos sistemas amazônicos - através da comensalidade, mas especificamente da refeição antropofágica compartilhada. Ou seja, no contexto ameríndio o comer junto é compreendido como sendo uma relação criadora de parentesco ou mesmo de mudança de perspectiva. Por outro lado, a cosmologia tupinambá era claramente um sistema predatório, porque reproduzia-se a partir da captura de elementos do exterior.

Dessa maneira, continuando a entender a guerra como provida de elementos de continuidade com a caça, a antropofagia tupinambá não era concebida pelos índios com um canibalismo literal. No momento da refeição antropofágica propriamente dita comia-se apenas um corpo um cozido, desprovido, então, da sua substância essencial. Nesse sentido, "a similitude entre animais e humanos se dá no plano da alma, comer o corpo da presa não seria uma forma de canibalismo" (ibid.: 33). A refeição antropofágica do inimigo morto no terreiro da aldeia se inscreve, de acordo com as concepções ameríndias, no âmbito da comensalidade, enquanto a ato canibal em si - a predação ontológica - é uma relação exclusiva do matador. O matador consistia, a partir disso, numa figura chave, porque ele era o verdadeiro canibal. Cabia unicamente ao sujeito executor da vítima a perpetração da relação de predação e, por esse motivo, apenas ele adquiria um elemento metafísico proveniente do inimigo, o qual pode ser designado por alma, espírito, sopro ou outras categorias de diferentes teores.

Após o sacrifício, o matador entrava em sua maloca para iniciar um período de intenso resguardo. Ao findar o tempo de reclusão, ele anunciava à todos seu novo nome e, enquanto isso, as mulheres mais idosas da tribo jogavam cinzas em suas costas. Logo em seguida, eram feitas incisões no corpo do sacrificante no intuito de que ele preservasse para sempre, maculado em seu corpo, a memória do inimigo. De acordo com Florestan, os resguardos dos Tupinambá permitiam que a alma imortal do sacrificado fosse lograda e, ao mesmo tempo, tornar-se dominada, como um animal de estimação arredio que 
transformava-se, durante o resguardo, num ser dócil. Conforme essa visão, a troca de nomes serviria mais para iludir o espírito da vítima do que para atribuir um status ao matador.

Ao olharmos as práticas observadas por um matador araweté, podemos encontrar uma certa analogia com os Tupi do século XVI. Segundo Viveiros de Castro, após ocasionar a morte ou mesmo o ferimento de um inimigo, o matador volta para a aldeia e permanece por cerca de cinco dias num estado associado à morte física de sua pessoa. Nesse período, o matador não se alimenta, vomitando de forma repetida o sangue do inimigo que está tomando seu corpo. $\mathrm{O}$ indivíduo passa por uma metamorfose semelhante a que ocorre com um corpo de um cadáver, sentido até o cheiro de putrefação e ouvindo barulho de urubus.

Como já enfatizamos, o sacrificante tupinambá era obrigado a se abster da carne do inimigo abatido. Enquanto isso, entre os Araweté, o matador corria riscos mortais apenas com o simples tocar em sua vítima. Além do mais, há um interdito sexual de algumas semanas, pois durante a relação com o matador a mulher corria sérios ricos de ser contaminada com sêmen do espírito do inimigo e vir a padecer. O resguardo acaba quando o matador recebe por meio de sonhos cantos e nomes, esses para serem usados para designar recémnascidos. Finalmente, o inimigo e seu matador "tornam-se 'como apihi-pihã'. Apihi-pihã é o nome da relação mais valorizada na sociedade araweté" (Castro 2002: 273). Como o espírito da vítima jamais deixa o matador, esse se torna um ser ambíguo e a qualquer momento pode se revoltar contra seus companheiros.

Já entre os Parakanã (também remanescentes tupi), o matador adquire os potenciais da vítima por contágio de uma substância denominada kawahiwa (gordura-mágica). Para Fausto (2001: 317), "é sugestivo que seja um outroimaterial da parte mais apreciada da carne, a gordura". Contudo, a kawahiwa faz com que o matador se torne um ser pouco sociável, podendo, por isso, voltar-se contra os seus. A proposta mais interessante de Fausto, porém, é perceber a guerra ameríndia através do conceito de consumo produtivo. Para ele, a guerra nestas sociedades não pode ser abordada por meio de um discurso que dá preponderância à reciprocidade, pois entre os Tupinambá, por exemplo, o belicismo também representava destruição (predação) na medida em que os inimigos eram "gastados" no terreiro.

Mesmo assim, "o consumo é não apenas perda, mas gasto produtivo: a morte do inimigo produz em casa corpos, nomes, identidades, virtualidades de existência - a morte fertiliza a vida, não necessariamente como um ciclo fechado de troca de energia, mas como um ciclo aberto e assimétrico (mesmo quando circunstancialmente equilibrado)" (ibid.: 328). Em síntese, se opondo aos sistemas estatais, a guerra tupinambá não buscava a depreciação do inimigo, ao contrário, sua intenção, ao permitir a existência dele por um certo 
período na aldeia, compartilhando das mesmas condições que os demais, era valorizá-lo em sua individualidade, pois assim se obteria "maior produtividade sociocosmológica" (ibid.: 329).

\section{Profetismo}

No que concerne aos aspectos da vida religiosa dos Tupinambás, assim como dos grupos Guarani, a maioria absoluta dos autores tende a pontuar a busca da Terra Sem Mal ( $Y$ vy marãey) como o fator mais relevante sob o qual está assentado boa parte das crenças desses indígenas. No entender de Melià (1990: 33), por exemplo, essa empreitada de caráter religioso se caracteriza por ser a razão essencial dos deslocamentos guarani e, além disso, mostrou ser o principal elemento agregador "na construção do modo de ser guarani". Os jesuítas e colonos portugueses que vieram residir em terras brasileiras no primeiro século da conquista costumavam a designar os movimentos religiosos dos Tupi-Guarani através do termo santidades. Conforme a abordagem do historiador Ronaldo Vainfas (1999: 51), os cultos classificados pela lógica do colonizador como santidades poderiam ter um caráter meramente ritual ou, não necessariamente excluindo a primeira forma, seriam pautados por migrações a uma região específica.

Mas como seriam as santidades manifestas em cerimônias rituais? Segundo boa parte da bibliografia a respeito dos grupos habitantes da costa litorânea no século XVI, as santidades rituais eram cultos normalmente comandados por índios errantes chamados pelos próprios nativos de caraíbas ou pajé-açu. Então, esses pregadores nômades tupi-guaranis, "apresentando-se como a reencarnação de heróis tribais" (Queiroz 1965: 143), possuíam o hábito de andar de aldeia em aldeia discursando sobre a Terra Sem Mal e a mitologia tupi-guarani, por meio de cerimônias coletivas envolvendo a dança, o canto, a ingestão de tabaco e bebidas alcóolicas. Schaden (1959: 42), ao discorrer sobre mitologia indígena, tenta convencer-nos da idéia de que todos os pajés são considerados pelos membros dos seu grupo um herói de pequena magnitude, enquanto seus heróis-civilizadores seriam percebidos pela cosmologia ameríndia com sendo pajés portadores de poderes mágicos extraordinários.

Com o intuito de evidenciar melhor a importância desses feiticeiros itinerantes na vida cotidiana dos Tupinambá, Alfred Métraux (1950: 42) recorre a análise das características de um dos seus heróis mitológicos. Conforme a interpretação do autor dos cronistas quinhentistas, Maire-monan - heróicivilizador extremamente valorizado entre as tribos litorâneas no século XVI assumi a forma de um feiticeiro de caraterística inigualáveis. Na mesma proporção que os caraíbas tupi, Maire-monan vivia em reclusão, afastado do convívio social, e em constantes jejuns alimentares. Além do mais, os 
Tupinambá "julgavam-no não somente dotado de poderes ilimitados, mas ainda senhor da ciência completa dos fenômenos naturais e dos mistérios ritualreligiosos". Maire-monan era responsabilizado pela instituição de vários rituais mágicos e religiosos, por determinar algumas proibições alimentares - a carne de animais vagarosos era tabu entre os grupos da costa - e pelo ensinamento de práticas arraigadas entre os Tupinambá, como "o costume da tonsura, da epilação e do achatamento do nariz dos recém-nascidos".

Outra narrativa mitológica registrada entre os Tupinambá é a de um filho de Maire-monan, designado pelos índios da região da Bahia de Sumé herói-civilizador associado por alguns missionários a São Tomé. Em um tempo remoto, Sumé teria visitado esses índios lhes ensinando algumas técnicas agrícolas, sobretudo a respeito da manipulação da mandioca, porém, em uma demonstração de ausência de reciprocidade, os índios acharam por bem devorálo. Com o objetivo de se salvar de sua própria refeição canibal, Sumé teria dado um salto em direção à ilha de Maré deixando as marcas dos seus pés imprimidas em uma rocha (H. Clastres 1975: 23; Métraux 1950: 52). Tamendonare e Ariconte, os filhos de Sumé, por sua vez, estariam ligados no ciclo de mitos tupinambás ao cataclisma do dilúvio. De acordo com $\mathrm{H}$. Clastres (1975: 25), os dois irmãos possuíam uma natureza bastante distinta e, por esse motivo, viviam em constantes atritos. Em uma das suas acaloradas discussões, Tamendonare, demostrando sua irritação, bateu com uma força extrema contra a terra provocando um buraco por onde começo a sair uma quantidade enorme de água. Essa fonte d'água provocou uma inundação e, interessados em se salvarem, Tamendonare e Ariconte, acompanhados de suas respectivas mulheres, trataram de se abrigarem no alto de duas árvores existentes no topo das montanhas mais altas da região. No mito, o resultado natural do dilúvio seria o perecimento de todas as espécies animais e dos homens, "com exceção dos dois casais, de quem nasceram dois povos inimigos: os tupinambás e os tamoios".

Os Chiriguano - índios tupi-guarani habitantes do Chaco boliviano -, segundo Métraux (1950: 56-7), por exemplo, se utilizam da mitologia para explicarem a aparente superioridade técnica dos brancos, em um caso que encontra análogos em muitos outros povos ameríndios. Segundo esses índios, Aguara-tunpa, após o findar da criação, colocou na frente dos antepassados dos índios e dos brancos todas as armas existentes. Os primeiros encantados com a leveza do arco e da flecha acabaram deixando as armas mais pesadas, como os fuzis e os sabres, para os antepassados dos europeus e, por isso, nos dias atuais, estes possuem uma grande vantagem em relação aos indígenas. O mais curioso, no entanto, é notar que os Tupinambá, assim como as populações do México e do Peru, nos momentos iniciais da conquista, entenderam a chegada dos colonizadores como sendo um regresso dos seus heróis-civilizadores, mais 
especificamente, os povos da costa litorânea consideraram os europeus filhos de Maire-monan.

A partir da bibliografia especializada, podemos constatar uma similaridade da mitologia existente entre os Tupi-Guarani. Nesse sentido, os Tupinambá, assim como os Guarani e os Chiriguano, possuem um heróicivilizador responsável pela existência, ensinamento e a instituição dos seus traços sociais mais representativos. Após ter concedido tantas dádivas aos seus antepassados, esse herói se retiraria "para uma espécie de paraíso terrestre, estância dos mortos e de alguns vivos favorecidos" (ibid.: 67). Entretanto, esse herói-civilizador responsável também pela destruição do mundo em épocas passadas - através de uma inundação ou de um incêndio -, conforme a mitologia ameríndia, voltará a fazê-lo em um tempo futuro. É dentro dessa visão pessimista da realidade futura que se insere a busca da Terra Sem Mal, pois essa crença Tupi-Guarani em um mundo livre da morte e onde os alimentos nasceriam espontaneamente, sem nenhum dispêndio de energia humana, "está essencialmente vinculada à convicção de que a terra será, mais uma vez, destruída” (H. Clastres 1975: 29).

Os Guarani do Brasil meridional de hoje podem ser divididos, de acordo com Schaden (1974: 02), em três grupos essenciais: "os Nãndéva (aos quais pertencem os Apapokuva, que se tornaram famosos pelo trabalho de Curt Nimuendajú), os Mbüá e os Kayová". A mitologia dos Guarani também está impregnada de elementos representativos da Terra Sem Mal, sobretudo entre os Apapokuva. Esses índios sustentam a crença em Nyuanderykey, um pajé detentor de poderes ilimitados, figura muito similar ao Sumé dos Tupinambá do século XVI. A morada de Nyuanderykey, localizada em um ponto geográfico específico possível de ser atingindo em vida - nas palavras dos pajés apapokuva, em direção ao sol nascente -, é o lugar onde está situada a Terra Sem Mal, o mito tupi-guarani do Yuy-marãey.

Possuindo uma cultura permeada por traços caracteristicamente de região florestal, os Guaranis sempre evitaram, de modo geral, a construção dos seus padrões de vida em localidades do Brasil central dominadas por extensas planícies abertas. Dessa maneira, estabelecendo-se quase sempre em regiões de mata densa, esses grupos indígenas possuem dentre suas principais atividades econômicas a agricultura combinada com atividades de caça. A forma de concepção das aldeias guaranis, diferentemente dos Tupinambá quinhentistas, são marcadas por habitações mais ou menos isoladas uma das outras, congregando geralmente apenas uma família nuclear ou, no máximo, uma família extensa. Distinguindo-se ainda mais das demais culturas da região baixa da América do Sul, os Guarani não tem o hábito de institucionalizar uma região central em suas aldeias, "a não ser que se considere como tal a habitação do ñanderú, chefe religioso, ou o oýguatsú, casa de festas religiosas” (ibid.: 25). 
Então, através da interpretação das imagens visualizadas durante um sonho, os pajés tupi-guaranis reuniam uma quantidade variável de adeptos e partiam rumo à Terra Sem Mal, pois apenas desse modo seria possível escapar da tragédia iminente. A tradição apapokuva, recolhida por Curt Nimuendaju (1987: 09), situava por vezes o paraíso terreal no centro da terra, "mas a maioria a punha no leste, além do mar". Enquanto isso, as ações classificadas por Vainfas (1999: 64) como sendo típicas de uma "santidade como movimento", eram perpetrada pelos Tupinambá do século XVI se caracterizando, principalmente, por migrações coletivas rumo ao interior do território brasileiro ou por assaltos contra propriedades agrícolas do colonizador.

Como já vimos anteriormente, na concepção dos Tupi, as santidades eram cerimônias que buscavam teatralizar as aspectos presentes no mito da Terra Sem Mal, sendo que suas prováveis conseqüências eram as migração em direção ao interior. Como o mundo dos Tupinambá era pautado numa economia na qual a caça e o cultivo de produtos como o milho e a mandioca tinham preponderância, a Terra Sem Mal poderia ser considerada uma antítese da realidade cotidiana vivida por esses índios. Assim, quando atingissem a morada dos deuses, as mulheres não precisariam mais se preocupar com o trabalho na lavoura e os homens, por sua vez, poupariam seus esforços nos empreendimentos de caça, pois "os frutos cresceriam sozinhos na terra, e as flechas caçariam por conta própria no mato; as velhas se tornariam moças e não haveria necessidade senão de bailar, cantar, festejar, beber e fumar" (ibid:1056).

No entender de H. Clastres (1975: 31-8), a Terra Sem Mal dos TupiGuarani era baseada em uma concepção dionisíaca de encarar a vida, porque, diferentemente do paraíso celeste cristão, a terra ideal tupi é regida por excessos, bebedeiras e festas. Dentro da cosmologia desses grupos indígenas, a figura central do xamã e a instituição do xamanismo, presente em boa parte das culturas ameríndias, geralmente com funções prioritariamente mágicas, ganha feições religiosas sobremaneira entre os Guarani. Contudo, deve-se deixar claro que, igualmente as outras culturas ameríndias, os xamãs tupi também eram basicamente homens ambivalentes admirados graças aos seus dotes de curador de doenças ou, muitas vezes, temidos, odiados e até mortos por acusação de utilizar seus poderes de maneira malfeitora.

Depois disso, porém, um dúvida central que persiste seria como se dá o processo de distinção entre xamã (pajé ou feiticeiro) e caraíba (pajé-açu, caraí, santidade ou profeta)? Métraux (1950: 153-9) sugere, primeiramente, que para se tornar uma pajé reconhecido por todos os membros de sua tribo era necessário demostrar efetivamente seus dotes através de curas de doenças e de profecias concretizadas. Entre os Tupinambá, cada aldeia possuía alguns desses 
feiticeiros incumbidos de tarefas de curandeiro e de chefia de rituais religiosos. No momento em que um pajé adquiria um reconhecimento para além de suas dimensōes territoriais era chamado de caraíba pelos Tupinambá da costa ou caraí pelos Guarani do Paraguai. De acordo com H. Clastres (1975: 40-1), os caraís se distinguiam dos xamãs principalmente por não coabitarem nas aldeias tradicionais. Nesse sentido, o afastamento do âmbito social parece ser uma peculiaridade dos indivíduos portadores do status de caraí, evitavam manter contato freqüente com os demais, jejuavam intensamente e evitavam as atividade laborais. O caráter nômade dessas entidades, legitimando o mito da Terra Sem Mal por meio dos seus discursos, os tornou completamente desvinculados de relações de parentesco ou afinidade com uma aldeia ou com uma rede de alianças de aldeias.

Os jesuítas, depois de evidenciarem a dimensão da influência dos caraíbas, adotaram uma estratégia de evitar o confronto direto com esses líderes religiosos. Geralmente, buscava-se atraí-los para as localidades das reduções, concedendo benefícios a sua pessoa no sentido de angariar a sua confiança e a sua submissão. Por outro lado, havendo uma resistência maior, os padres criavam modos de humilhar a santidade perante seus seguidores, normalmente questionando seus poderes xamânicos. Nas palavras de Maria Isaura Pereira de Queiroz (1965: 153), esses chefes-feiticeiros eram "exibidos na praça central da redução, os índios convertidos dançavam em torno deles, caçoando e exigindo que mostrassem seus poderes divinos. Em seguida, eram enviados para missões longínquas, onde a existência no meio de silvícolas de tribos diferentes das suas e já convertidos acabaria por quebrantar-lhes a revolta". Declaradamente, então, os xamãs se tornaram os maiores inimigos dos missionários, pois seus discursos enfatizavam a necessidade de permanecerem fiéis aos pressupostos religiosos herdados de seus antepassados. Além do mais, na visão de mundo cristã dos jesuítas, esses índios feiticeiros representariam uma ameaça ainda maior na medida em que seus poderes, não sendo provindas de instâncias sagradas, só poderiam ter uma origem de caráter profana.

Conforme alguns relatos (Métraux 1950: 169; H. Clastres 1975: 19)), entre os Guarani os xamãs mais habilidosos durante a vida atingiam um status de veneração após sua morte. Em lugares afastados do olhar de condenação do colonizador, esses índios praticavam uma espécie de culto dirigidos às ossadas dos grandes xamãs. Além disso, os Guaranis costumavam fazer ofertas sobre o local onde estavam sepultados esses grandes feiticeiros, conşultando-os no sentido de obterem deles profecias ou pedidos infalíveis. Outro atributo importante dos pajés, no período em que viviam sua existência terrena, era a possibilidade de se transformarem em espécies animais, as quais o jaguar seria a forma mais comum assumida por essas entidades no objetivo de angariarem uma disfarce. O interessante é notar que os Guarani, mais especificamente os 
Ñandeva (Nimuendaju 1987: 34; Schaden 1974: 112), possuem uma concepção predominantemente dualista da alma, dividindo-a em dois segmentos: o ayvucué - responsável pelas ações boas ou de apaziguamento - e o acyiguá alma animal com sede na nuca determinadora da personalidade humana. Então, assim como os xamãs guarani possuem um acyiguá de jaguar, seus principais inimigos, os Kaingang, igualmente são considerados detentores de um acyiguá de jaguar ou de gato do mato. Assim, o xamã entre os Guarani parece ser associado ao jaguar e ao inimigo simultaneamente. Como no modelo traçado por P. Clastres (1986: 100), o feiticeiro guarani também seria portador de uma ambivalência, ou seja, "ao mesmo tempo respeitado, admirado, temido", graças as seus dons mágicos é considerado pelos seus companheiros de tribo tanto "senhor da morte como da vida".

Contudo, no entender de Nimuendaju (1987: 45), torna-se necessário explicar melhor a concepção dualista da alma guarani para não atribuí-la a uma influência cristã. A partir disso, então, é preciso reconstruir o significado tanto do ayvucué quanto do acyiguá, pois ambos não pressupõe, como na dualidade juidaico-cristão, bem e mal, mas representam o "contraste entre os diferentes temperamentos humanos: ao fleumático-melancólico se contrapõe o sanguíneocolérico". Cabe ressaltar, também, o fato dos índios Kaingang, vizinhos dos Guarani, se considerarem realmente ligados por relações de parentesco ao jaguar (ibid.: 118). Em acréscimo a isso, sua estrutura social é segmentada em metades, isto é, uma facção da sociedade pertence à metade Kamé e a outra à metade Kañerí. A concepção do comportamento humano entre os Kaingang, distintamente dos Guarani, está associada aos seus segmentos sociais, pois os indivíduos pertencentes aos Kamé seriam detentores de um temperamento fleumático-melancólico, enquanto os Kañerú manifestariam tendências prioritariamente sanguíneo-colérica. Em síntese, nos salta aos olhos uma semelhança e uma diferença entre as cosmologias kaingang e ñandeva: primeiramente ambos dividem a personalidade humana de forma dualista e, em segundo lugar, os Kaingang se utilizam desta visão dicotômica na estruturação da sociedade, enquanto os ñandeva concebem a pessoa sobrenaturalmente portadora de duas almas.

Nimuendaju se tornou o primeiro estudioso tupi-guarani a ressaltar a importância para esses índios do mito da Terra Sem Mal. Em sua abordagem precursora, através de um estudo minucioso sobre os Apapokuva, Nimuendaju (1987: 75) ressalta a existência nesse grupo guarani de quatro divisões sociais no que condiz ao xamanismo: no primeiro segmento, estariam incluídas todas as pessoas não portadoras de qualquer dote xamânico. Já na segunda seção, pertenceriam os indivíduos que receberam alguns cantos, mas só os utilizam em âmbito doméstico. A terceira classe, por sua vez, congrega os pajés propriamente ditos, esses possuindo a função de comandar algumas danças 
rituais e o título de Ñanderí (homens) e Ñandecý (mulheres). Os indivíduos que chegam ao último estágio eram considerados pajés-principais e, além de liderarem socialmente o grupo, eram incumbidos de comandarem a festa Ñemongaraí - realizada "uma vez por ano, na época em que os frutos da lavoura, especialmente o milho, estão verdes, isto é, entre janeiro e março" (ibid.: 89).

No início do século XX, Nimuendaju (1987: 104) relata que índios guarani do extremo sul do Mato Grosso haviam, desde de meados do século XIX, iniciado um movimento de migração em direção ao litoral brasileiro. Esses índios não duvidavam da existência do Yvy marãey, entretanto, achavam não mais ser possível atingi-lo pelas vias normais graças ao fato de se utilizarem da alimentação "pesada" concedida pelos brancos. Diante da evidência das migrações guarani, chega-se a propor uma hipótese bastante ambiciosa: supõe-se que o domínio Tupi-Guarani da costa litorânea presenciado pelos primeiros colonizadores seria fruto, igualmente, de uma intensa migração provinda do interior em busca da Terra Sem Mal. E, no intuito de sustentar sua tese, Nimuendaju (ibid.: 107-8) considera o estabelecimento dos Tupi no litoral um processo recente, pois, nos momentos iniciais da conquista, esses indígenas demostravam um ignorância, raramente presente em povos costeiros, da arte da pesca e da navegação. De acordo com essa análise, a invasão tupi do litoral não ocorreu devido à "sua força de expansão bélica", o motivo talvez "tenha sido outro, provavelmente religioso, sua habilidade guerreira apenas lhes possibilitou realizar, até certo ponto, os seus planos".

Em um estudo detalhado sobre a religião tupinambá, Métraux (1950: 223) considera o acesso ao paraíso mitológico tupi uma dádiva somente concedida aos grandes guerreiros e aos matadores mais exímios. A partir dessas considerações, Métraux, diferentemente de Nimuendaju, sugere uma ligação maior entre guerra e profetismo. Em acréscimo a isso, delineia a hipótese de que quanto determinadas populações são subjugadas o processo de mudança desencadeado por essas operações são rejeitados através da formulação de uma espécie de idade de ouro localizada num passado ideal e livre de dominações. Dessa forma, segundo Métraux (1950: 328-9), os rituais de exaltação coletiva e as migrações tupinambás em direção ao interior, realizadas no século XVI, estariam inseridas nesta lógica messiânica apenas de reação à colonização. A busca da Terra Sem Mal seria, então, uma alternativa radical para evitar os desígnios da história, no sentido da preservação da cultura tradicional.

Ao discorrer sobre a cultura guarani, Schaden (1974: 135) concebe a Terra Sem Mal como um lugar situado ao leste onde esses índios encontrariam seus entes falecidos. De acordo com seus escritos, os Guarani acreditam que o seu paraíso ideal se caracteriza por ser uma localidade na qual todas as agruras desse mundo não teriam vez. No entanto, as contribuições mais importantes de 
Schaden estão contidas nas suas análise da aculturação guarani em face do cristianismo. Sua hipótese mais reveladora consiste em considerar os discursos guarani de aparente conversão ao cristianismo apenas como uma dissimulação frente as discriminações perpetradas pelos brancos. Segundo o autor, até algumas práticas cristãs como o batismo das crianças, o casamento religioso e a colocação de cruzes sobre as sepulturas, são realizadas pelos Guarani com "a função de testemunhar um cristianismo na realidade inexistente" (ibid.: 136). Em conclusão, o sistema religioso guarani seria a instituição mais importante no processo de resistência angariado contra a cultura ocidental.

Inovadora na discussão de movimentos messiânicos no Brasil, Queiroz (1965: 161) compõe uma classificação bem pertinente para esses fenômenos ainda usada atualmente. Segundo a autora, os movimentos indígenas de resistência à colonização podem ser divididos em dois segmentos: os primeiros seriam movimentos sincréticos portadores de uma "mitologia nova", resultado direto do contato com a cultura européia e da conseqüente reformulação de elementos nativos. O outro tipo de classificação, entretanto, abrangeria movimentos estritamente influenciados por categorias de pensamento nativas. O movimento em busca da Terra Sem Mal iniciado tanto pelos Guarani do século XIX quanto pelos Tupinambá do século XVI, no entender de Queiroz (1965: 167), se encaixariam nessa última categoria. Considerando, então, as migrações tupi-guaranis com obras puras produzidas pela cosmologia indígena, a autora reitera a hipótese de Nimuendaju, considerando a possibilidade da invasão tupi do litoral, anterior à conquista, ser um dos frutos da procura da Terra Sem Mal. No que condiz ao primeiro tipo de movimento messiânico, Queiroz (ibid.: 188) insere as chamadas santidades, cultos sincréticos rebeldes geralmente orientados "por indígenas que, educados (...) nas missões, ou tendo sido convertidos, efetuam uma ligação entre a religião nativa e a cristã.

Por outro lado, em seu livro clássico sobre o profetismo tupi-guarani, H. Clastres (1975: 11) nos alerta, primeiramente, sobre as mudanças na estrutura social guarani provocadas graças à influência jesuíta: "a forma da aldeia e das casas, as atividades cotidianas, a economia, o sistema de parentesco, as relações intertribais... tudo isso foi transformado". Contudo, a essência da antropologia dessa autora parece estar numa suposta tensão do plano político com o religioso na sociedade tupi-guarani. Conforme sua abordagem, no período inicial da conquista, a dinâmica interna dessa sociedade estava ameaçada graças a existência de forças centrípetas, isto é, de chefes "cuja autoridade era reconhecida nas escalas da província". A busca da Terra Sem Mal consistia-se, então, numa empreitada que "exprime sobretudo forças centrífugas, negadoras do social" (ibid.: 45). As pregações dos caraíbas incentivavam a interrupção de práticas organizadoras do social como a caça, o cultivo e as regras matrimoniais. Por outro lado, o discurso profético daria 
ênfase a guerra e o canibalismo instância que, segundo H. Clastres seriam "a negação das regras de aliança”. As críticas a esse modelo são bastante comuns, Viveiros de Castro (1987: xxx), por exemplo, não localiza no profetismo uma instância "negadora do social", pois, no seu entender, a guerra e o canibalismo eram "o próprio fundamento da sociedade Tupi-Guarani".

Além disso, outra polêmica presente na interpretação do fenômeno do profetismo entre os Tupi-Guarani formulada por H. Clastres (1975: 51) é a idéia da ausência de influências européias na irrupção da busca da Terra Sem Mal. Em síntese, esse movimento não teria um caráter messiânico, pois ele estaria inscrito apenas na lógica interna da sociedade indígena, nenhum elemento ocidental contribuiria no desencadear do profetismo. Nesse sentido, "todo o contexto, todos os elementos do profetismo já estão presentes: as personagens dos caraís, com sua posição de exterioridades espacial e genealógica; o tema da Terra sem Mal; o mito da destruição da primeira terra; e a crença num cataclisma futuro". Segundo Vainfas (1999: 44), a tese de H. Clastres é equivocada justamente por ignorar as influências do colonialismo "no surto migratório dos tupi no século XVI".

Depois dessa análise da Terra Sem Mal, nos atendo com maior afinco aos seus aspectos religiosos, podemos nos questionar perguntando qual a relação desse mito com o ambiente natural freqüentado pelos Tupi-Guarani? Conforme Melià (1990: 34-5), “a vida guarani nunca se liberta, nem se abstrai da questão da terra", pois o ambiente pode provocar uma variação significativa nas condições "de povoamento, na dimensão de suas aldeias e na densidade de sua demografia". No entanto, devemos deixar claro que, obviamente, os Guarani não são povos determinados pelo ambiente, muito pelo contrário, geralmente seus padrões de vida são desenvolvidos em áreas seletivamente escolhidas. Por isso, a cultura guarani se caracteriza, sobremaneira, por um conhecimento bastante denso dos tipos de solo adequados ou não adequados para o plantio de vegetais ou frutos específicos. Para os Guarani a terra não é, entretanto, uma entidade divinizada, mas a experiência cotidiana compartilhada e as práticas tradicionais perpetuadas em suas delimitações estão permeadas de aspectos sobrenaturais.

Desse modo, os Guarani possuem o costume de delinearem uma terra ideal, a qual teria sido criada "pelo Primeiro Pai e posta ao cuidado, eventualmente, de outros seres divinos, que a protegem e defendem" (ibid.: 38). Porém, se existe uma concepção de terra perfeita bem estruturada, em contraposição, a instabilidade para ser uma característica primordial dessa terra, pois a iminência de sua destruição parece ser algo permanente na mitologia tupi-guarani. Temáticas recorrentes, as catástrofes naturais - inundações, secas, ventos fortes - parecem serem os indícios principais da destruição da Terra por uma entidade sobrenatural. Conforme o relato de Schaden (1974: 163), por 
exemplo, a crença guarani num fim do mundo próximo é algo bastante arraigado entre esses índios. Algo que não se encontra nessa profecia, contudo, como nos mostra a citação a seguir, é uma homogeneidade no que condiz ao tipo de catástrofe que seria responsável pela destruição do mundo:

Os Mbüá acreditam num Dilúvio iminente, num Incêndio Universal ou, ainda, numa prolongada escuridão. Para os Nandevá, a catástrofe que os ameaça consiste principalmente num incêndio geral seguido do desmoronamento da superfície đa Terra, representada como disco. Entre os Kayová (...) se encontra a descrição duma cena, rica em pormenores, em que se fala em cavalos voadores, macacos flechadores e outros tipos de monstros.

A figura do "xamã-pai" parece ser, de modo geral, a mais comum forma de liderança político-religiosa no contexto da sociedade guarani atual. Nesse sentido, "a comunidade guarani se forma junto ao pai, que promove as condições da reciprocidade generalizada, e junto ao xamã, que ritualiza e representa a reciprocidade de palavras, sem as quais o convite seria apenas um comer em comum". É nesse ponto, a preservação da reciprocidade comunitária, que, segundo Melià (1990: 42), a busca da Terra Sem Mal se insere.

Tendo como principal foco de análise um culto de caráter híbrido, Vainfas (1999: 73-78) se atém ao estudo da santidade de Jaguaripe - região do Recôncavo Baiano. Esse movimento ganhou a atenção das autoridades coloniais, e até da Inquisição portuguesa, em sua passagem pelo Brasil, graças ao fato de um poderoso senhor de engenho da localidade abrigá-lo por algum tempo em seus domínios. Por meio da intromissão de Fernão Cabral de Taíde, dono de um engenho escravocrata, a existência de uma seita indígena considerada profana chegou até os nossos dias.

O líder da santidade de Jaguaripe era o caraíba Antônio, índio "meio cristão, meio tupi", fugitivo do aldeamento jesuítico da ilha de Tinharé. "Dotado de poderes divinos, como os heróis da mitologia tupi, o caraíba-mor da santidade dizia ser capaz de metamorfosear os outros e a si mesmo, de transformar as velhas em moças, de fazer as plantas crescerem sozinhas". Além do mais, Antônio dizia ser Tamandaré, herói mítico tupinambá que escapou do dilúvio. Em um história permeada de sincretismo, Antônio anunciava sua salvação do dilúvio junto a Noé - referência à mitologia cristã - por motivo de ter subido em uma palmeira - citação do mito tupinambá. Antônio também era chamado de "papa", enquanto seu auxiliar era o "segundo papa" ou Aricute irmão de Tamandaré que se salvou do dilúvio ao permanecer sobre um jenipapeiro, conforme a mitologia tupinambá. E, diante da crescente influência da figura da Virgem Maria na catequese jesuítica, a santidade de Jaguaripe, contrariando a tendência tupinambá de possuir uma mitologia determinada pela patrilinearidade - um espelho da sociedade -, adotou em sua "corte celeste" uma Mãe de Deus. 
Ao tecer comentários sobre o profetismo tupi-guarani, Vainfas (1999: $46,50)$ tem um posicionamento pautado na tentativa de conciliar as distintas tendências no estudo desse movimento. Segundo ele, as migrações do século XVI estavam realmente estavam inscritas em um dinâmica originalmente nativa, provavelmente anterior à conquista. Porém, com o andar do processo de colonização, a busca da Terra Sem Mal ganhou feições anticolonialistas. Impedir a desestruturação da cultura nativa tornou-se sua principal finalidade, por mais que alguns elementos europeus tem sido incorporados. Por isso, a rota da Terra Sem Mal foi subitamente alterada, pois frente a ameaça da submissão o litoral deixava de ser um paraíso, apenas o interior, longe da influência européia, poderia representar a Terra Sem Mal dos Tupi-Guarani.

\section{Considerações Finais}

É importante ressaltar o fato da nossa pesquisa ter procurado delinear um panorama a respeito das distintas tendências de interpretação das instâncias sociais presentes nos grupos tupi-guarani em diferentes temporalidade. Entretanto, nosso objetivo principal foi discorrer sobre os Tupinambá da costa litorânea no século XVI, através de um debate entre os autores mais diversos. Outro aspecto fundamental a ser destacado, por vezes redundantemente comentado pela bibliografia especializada, é o caráter essencialmente inovador da análise dos costumes dos povos indígenas quinhentistas por meio do preenchimento de algumas lacunas possibilitadas graças a etnologia amazônica desenvolvida nas últimas décadas. Nesse sentido, nos pareceu bastante fértil a idéia de se apropriar de alguns conceito surgidos a partir do diálogo com as sociedades indígenas contemporâneas.

Além do mais, nossa pesquisa igualmente se insere em um debate acalorado, a respeito do tratamento dado as sociedade indígenas habitantes do território brasileiro. Desse modo, nos parece bastante nítido, algumas posturas ideológicas assumidas pelos autores aqui analisados, mesmo que, em primeira instância, esses posicionamentos são transmitidos apenas de maneira implícita. As diferentes teorias construídas a respeito do contato dos Tupi-Guarani com os europeus durante o processo de conquista, assim como com a sociedade nacional atualmente, são bastante distintas. Algumas dessas teorias parecem abarcar um conceito de cultura bastante elástico, enquanto outras, talvez temerosas da desagregação étnica, procuram ocultar qualquer elemento de origem estrangeira tomados pelos índios, ao nosso ver, de acordo com as demandas angariadas pelo processo de resistência.

Enfim, tentamos não desvincular nenhuma das instituições sociais dos Tupi-Guarani de forma a fragmentar demais traços culturais desenvolvimentos de maneira integrada. Por isso, apesar da escolha, justificada através da análise 
da bibliografia existente, de dividir a pesquisa em três tópicos esperamos não ter cometido o equívoco de dar ao leitor uma impressão falsa dos Tupi-Guarani, na medida em que demografia, guerra, canibalismo e profetismo são temas completamente entrelaçados.

\section{Referências Bibliográficas}

BRANDÃO, Carlos Rodrigues. 1990. "Os Guarani: Índios do Sul, Religião, Resistência e Adaptação”. In: Estudos Avançados, 4(10): 53-90.

CASTRO, Eduardo Viveiros de. 1985. "Deuses Canibais: A Morte e o Destino da Alma entre os Araweté". In: Revista de Antropologia, (27-28): 55-90.

. 1987. "Nimuendaju e os Guarani". In: NIMUENDAJU, Curt. As Lendas da Criação e Destruição do Mundo como Fundamentos da Religião dos Apapocúva-Guarani. São Paulo: Edusp.

. 2002. A Inconstância da Alma Selvagem. São Paulo: Cosac \& Naify.

CASTRO, Eduardo Viveiros de. \& CUNHA, Manuela Carneiro da. 1986. "Vingança e Temporalidade: Os Tupinambás". In: Anuário Antropológico 85, pp. 57-78.

CLASTRES, Hélène. 1975. Terra Sem Mal. São Paulo: Editora Brasiliense. CLASTRES, Pierre. 1982. Arqueologia da Violência. São Paulo: Brasiliense. . 1986. A Sociedade Contra o Estado. Rio de Janeiro: Francisco Alves.

DEAN, Warren. 2002. A Ferro e Fogo. São Paulo: Companhia das Letras.

FAUSTO, Carlos. 1998. "Fragmentos de História e Cultura Tupinambá". In: CUNHA, Manuela Carneiro da (Org.). História dos Índios no Brasil. São Paulo: Companhia das Letras, pp. 381-96.

. 2001. Inimigos Fiéis. São Paulo: Edusp.

2002. "Banquete de Gente: Comensalidade e Canibalismo na Amazônia”. In: Mana, 8(2): 7-44.

FERNANDES, Florestan. 1963. Organização Social dos Tupinambá. São Paulo: Difusão Européia do Livro.

1970. A Função Social da Guerra na Sociedade Tupinambá. São Paulo: Pioneira.

HEMMING, John. 1998. "Os Índios do Brasil em 1500". In: BETHELL, Leslie. (Org.) América Latina Colonial I. São Paulo: Edusp, pp. 101-27.

LIMA, Tânia Stolze. 1996. "Os Dois e seu Múltiplo: Reflexões sobre o Perspectivismo em uma Cosmologia Tupi". In: Mana, 2(2): 21-47.

MELIÀ, Bartomeu. 1988. El Guarani Conquistado y Reducido. Asuncion: Biblioteca Paraguaya de Antropologia. 
1990. "A Terra Sem Mal dos Guarani”. In: Revista de Antropologia, (33): $33-46$.

MÉTRAUX, Alfred. 1950. A Religião dos Tupinambás e suas Relações com a das Demais Tribus Tupi-Guarani. São Paulo: Companhia Editora Nacional.

MONTEIRO, John Manuel. 1995. Negros da Terra. São Paulo: Companhia das Letras.

NIMUENDAJU, Curt. 1987. As Lendas da Criação e Destruição do Mundo como Fundamentos da Religião dos Apapocúva-Guarani. São Paulo: Edusp.

QUEIROZ, Maria Isaura Pereira de. 1965. O Messianismo no Brasil e no Mundo. São Paulo: Dominus Editora.

SAHLINS, Marshall. 1999. Ilhas de História. Rio de Janeiro: Jorge Zahar Editor.

SANTAMARIA, Daniel J. 1996. "Resistencia Anticolonial y Movimientos Mesianicos entre os Chiriguanos del Siglo XVIII". In: Anuario Escuela de História, (17): 169-98.

SCHADEN, Egon. 1959. A Mitologia Heróica de Tribos Indígenas do Brasil. Rio de Janeiro: Departamento de Imprensa Nacional.

. 1974. Aspectos Fundamentais da Cultura Guarani. São Paulo: Edusp.

SCHWARTZ, Stuart. 1988. Segredos Internos. São Paulo: Companhia das Letras.

VAINFAS, Ronaldo. 1999. Heresia dos Índios. São Paulo: Companhia das Letras 